\title{
The Storyteller in Contemporary Breton Literature: Redeemer of Orality and Symbol of Transgression
}

Sandrine TELXIDOR

T n April 2003, the $7^{\text {th }}$ edition of "Mythos," "the Festival of storytelling and oral arts" took place in Rennes, Brittany, France.' The organizers claimed: "We thought the storytellers gone for ever, engulfed by the clash of the media. They are back, because people need legends, myths and stories to live." 2 They are back indeed.

In this study, I am particularly interested in three authors from Brittany, France. Their names are Pierre-Jakez Hélias, Xavier Grall and Mona Thomas. I analyse the role they grant to the storyteller as the symbol of the imaginary and collective memory. While very little seems to connect these authors at first, I argue that on the contrary they anchor their storytellers in a very specific space and night-time, allowing them to revive a tradition and to regain total power in a contemporary world. Perpetuating certain cultural practices, the storyteller becomes essential to their writings. Hélias, Grall and Thomas hold on to this orality which they see as a treasure. I will first show how orality and the storyteller are linked to the survival of traditions, for oral stories become a way to revive a past cultural treasure. In that sense, the storyteller symbolizes the cultural transmission as he passes on the cultural heritage from one generation to the next. In the texts of Hélias, Grall and Thomas, the storyteller transcends the misconception of storytelling and turns it into a powerful "night lyric." He therefore becomes the symbol of both a collective memory and 
a cultural celebration, and most of all, the continuity of a legend and the redeemer of a whole society longing for memories and stories. Secondly I will highlight the fact that far from remaining a passive character, the storyteller transforms his gift for telling stories into a defiant act, using it as a source of liberation, exaltation and ultimately a way to transgress the barrier imposed by the French society, constricted by forbidden rules, in which he lives.

Storytellers have been literary authorities for many years. If the folktales first appear in the sixteenth-century B.C., they have become really popular in contemporary Eastern and African societies. ${ }^{3}$ They were called bards in Celtic civilizations. They turned into troubadours in seventeenth-century France. Today, they are the poets and the storytellers of rural contemporary societies. They can be found in many Francophone literatures, such as the Caribbean, the Haitian and the African. They appear in the texts of Tahar Ben Jelloun - (L'Enfant de sable), Calixthe Beyala and Maryse Condé (La Traversée de la Mangrove). Les Contes des mille et une nuits is a reference book on the matter. Other authors of France, such as Giono considered more canonical by the French intellectuals have inserted this very same figure in their writing. In Manosque des Plateaux, the narrator is a storyteller. Men of the villages gather around him, curious and anxious to hear the end of the stories. ${ }^{4}$ However, orality is still a contested term in contemporary literature. Along with oral history, orality may have made some comeback recently but it still tends to be depreciated in both French and Francophone literary works. Moreover, as critics always associate the storyteller with orality and oppose it to scripturality, they see this recurring figure as a symbol of minority writings, not to say secondary. Therefore, they usually dismiss the fact that the storyteller, far from being a trivial figure, embodies a very sacred and ritualised act. The French saying "la parole, c'est du vent!" literally meaning "oral word, it's all wind!" reflects the general consensus that orality tends to disintegrate in the act of speaking.

Hélias, Thomas and Grall, on the contrary, are profoundly attached to orality and the storytellers. In his texts, Hélias often regrets the invention of writing and of the press. In Lettres de Bretagne, he accuses them of having killed little by little the oral transmission and to have exacerbated the vanishing of folk-tales. He blames them for the disappearance of storytellers" "outbursts of inspiration." He would have agreed with Rousseau who once said: "Languages are there to be spoken, writing is really created to supplement the oral voice." Similarly, the main character of Thomas's texts La Chronique des choses called Danvez is continuously 
fighting the writing transcriptions in. He wanders on the roads of Brittany as a storyteller. Nomadic poet, he hopes to find a new inspiration in his vagrancy. While Danvez's disciple urges him to accept that his work be published, the poet replies: "Inconsequential. Immature. Presumptuous. Where does this foolishness of yours to publish come from! Publish!"” In fact, according to Danvez, the man who associates with books is possessed by the Devil!" (30). Books are therefore not only unnecessary but also far less valuable than the oral world. Storytelling is perceived as an unusual gift which suffices to transmit culture across time and links the community together.

As Walter Benjamin once said of the storyteller: "His natural gift is to narrate his life; his dignity is being able to tell it all." ${ }^{\prime}$ According to Hélias, storytelling is a special and uncommon gift. Not everyone can pretend to be gifted in such a way. ${ }^{9}$ Yet, one might ask who the storyteller is, and more importantly, one might wonder what his role and functions are in Breton texts. Undeniably, in Hélias's case, Hélias often promotes himself as the storyteller before anyone else. He transforms the stories he heard into a new version and claims the paternity as he gives them a new form. Moreover, while using the narrative "I" as an autobiographical motif, he attempts to replicate the interactive dynamic between himself and the reader, exactly as the storyteller would do, in front of a crowd. In his text, Le Quêteur de mémoire, he recalls his journeys within Brittany as he collected past stories from various storytellers. He explains how he transmitted them to the rest of his community longing for collective memories and to the Other the Other being everyone outside the Breton world. He describes how for twelve years he re-enacted tales in Breton language, live, on the radio with his partner Pierre Trepos. The fact that the author uses at that time the radio media is essential. We would like to suggest that in this specific example, Hélias dupes literacy. As Friedrich Kittler states in Gramophone, Film, Typewriter, Hélias describes how he found a manner to "faithfully manipulate the spoken word in ways that no longer require that speech be translated into writing (xii)." ${ }^{" 10} \mathrm{First}$, as Hélias chooses to use a new technology; he combines tradition and modernity and gives birth to a new modernized orality. Subsequently, he totally disregards scripturality insisting on the fact that a written form is unnecessary even in a contemporary Brittany. We'd like to suggest that if on one hand, the distance created by the media setting produces a gap between his audience and himself, making direct contact impossible and firsthand reactions difficult to control, Hélias nevertheless experiences a new way of storytelling in a modern world. He integrates the best of both 
worlds; the capacity to reach a wider public and yet, the possibility to share a very creative cultural heritage with them. At other times, however, Hélias does not represent himself as that oral symbolic figure In Le Cheval d'orgueil, he rather chooses two characters to promote orality: they are the grandfathers of the narrator and they connect different generations." They are still a voice from a different era and from another place, and act as oral archives. ${ }^{12}$ They still belong to the same social class and community.

In Hélias, Grall and Thomas, likewise, the storyteller belongs indeed to a specific social class. In Hélias's case, he's either a craftsman or a shoemaker. In Thomas's story, he can't read or write. As Walter Benjamin explains in "The Storyteller," the storyteller feels connected to craftsmanship. According to him, "if peasants and seamen were the past masters of storytelling, the artisan class was its university." As a peasant, the storyteller embodies the Breton language and the Breton world before anything else. But as he narrates stories around the fireplace and on the market place, he has only the one purpose in life to draw the whole community together. In all those portrayals, the storyteller is seen indeed as more than a simple maker of stories. Hélias gives him full power and a central position making him indistinguishable from his writing, because in the end, the storyteller is vital to his community and to the man Hélias himself has become. Often the author admits the influence of his grandfathers' storytelling gifts on him. As he grew up in an environment largely anchored in an oral society, he became a writer for whom a text without a voice and an orality would be a body without a soul. As the storyteller is the gatherer of old stories and myths, he becomes, beyond a source of knowledge, the master of the spoken act. He becomes the voice of Brittany that comes from different times and from different locations. He appears as the ambassador and mediator, since he stands at the crossroads of time and space. He recalls the cultural knowledge of his society as he manages to re-enact a past voice.

In Le Cheval d'orgueil, the narrator describes how the storyteller always tests his new stories on children first: "As soon as the sun sets, Grandpa starts to tell his stories to two or three energetic kids who soon gather along with six or seven others around him" (104). ${ }^{13}$ His expertise is multiple. His power ranges from songs and stories to riddles and nursery rhymes. In addition to being an entertaining character, he is also an educator and a moralist. Benjamin explains: "The real story contains, openly or covertly, something useful. The usefulness may, in one case, consist in a moral; in another, in some practical advice; in a third, in a proverb or maxim. In every case, the storyteller is a man who has counsel 
for his readers" (86). Like no one else, he educates the present and future generations, and always adds personal memories to those stories. Most importantly, he is the one who teaches the Breton language to the next generation. The young Hélias constantly recalls the times when his grandfather would teach him the days of the week, in Breton riddles: "My grandfather teaches me the days of the week which all start with 'di,' it is fun. 'Dilun, dimeurz, dimerher, diriaou, digwener, disadorn, disul. ...' He is so smart, I am amazed that his head has not exploded yet" (71) ${ }^{14}$ Choosing to educate the child in the Breton language is essential. In this case, the storyteller not only transmits a cultural concept but, most importantly, he passes on the Breton language that is being progressively lost in the community. He shares the cultural secrecy and intimacy that is inherent not only to the tales, but also, to the Breton language. Consequently, he underlines the strong ties that hold together the native language and the culture. Soon, he incarnates the tradition, the language and the History all together. The storyteller stands strong and still like a statue on his pedestal.

The richness of the story and the power of the storyteller are due to several factors. First, the tale is very malleable because it is transmitted from ear to ear. Therefore, it is impossible to restrain it, control it, and frame it. While the past is usually portrayed as fixed, chained, stored, magnified or hated, the past inherent to the story can escape the usual constraints. From the moment of its creation, it maintains a large degree of freedom. Secondly, as the storyteller tailors each story to a specific situation, it seems unique to each and every audience. It therefore becomes their tale, their legend. Since the storyteller is portrayed as the sole person to know and understand its functioning, he cannot be replaced. Even though the tale is partly fictional, never being an historical narration, it carries a certain genuine authenticity. The storyteller's stories are accepted by the community as authentic. It is mainly because he is the one rewording the story that everything he says becomes therefore legitimate and accepted by his peers. No one doubts his words because his stories are the myths that hold together his society. As he is the focus of the cultural network of the community, nobody criticizes his manners nor do they dare interrupt his storytelling, no matter how late it may get. Even when his tales and characters are largely subject to exaggeration, the audience believes in them. In La Nuit singulière, the storyteller tells about men killing the biggest wolves seen in Brittany, about fights to death lead by one man facing fifty ferocious animals. ${ }^{15}$ Countless times, the storyteller narrates hyperbolic stories that the audience accepts in 
suspension of disbelief. They blindly listen to his sayings. No one else outside of this specific setting would believe them. However, as dramatization becomes soon an essential part of the oral performance, everyone in the community is mesmerized by his words. Even the nickname given to the grandfather in Le Cheval d'orgueil, "John of Wonders," reveals the power given to him. The narrator claims that "the storyteller gives so many precise and detailed descriptions that even his heroes would believe in his telling." Bit by bit, his words prevail over reality. In Mona Thomas's La Chronique des choses, the storyteller is a blind man who spends his life on the road with his disciple, formulating a life-long poem and telling stories and songs in every village and city he encounters. He similarly represents the source of knowledge and the master of his art: "No matter the origins or their content, [his] words are as a music coming from within, no text can be found." ${ }^{16} \mathrm{He}$ is portrayed both as a living library and a vibrant music: "Danvez (the main character) tells stories in hundreds of ways, some the way he heard them, some the product of his imaginary world. ... We can hear people in the crowd say: this is the truth, things really happened that way. While for Danvez, truth can be multiple" (36-37). ${ }^{17}$ As soon as he arrives to a village, he appears as the messiah: "The singer arrives!" the crowd shouts. "Everyone winds his way through the crowd to listen to him, requesting his words. What an amazing memory he has, they say" (19-20). ${ }^{18} \mathrm{He}$ is seen as a sanctified human being. People repeat his name over and over (43) ${ }^{19}$ Once again, he is given total power by his peers, and ultimately by the author who calls him a monarch (43). Finally, the story is seen as the permanence of humanity. It pre-exists each storyteller and is never constrained in $a$ single lifetime. As folktales travel through the time, constantly being re-narrated, they allow cultural traditions and values to persist. Time has no effect on them. Each storyteller adds another layer each time, one that brings a new complexity and intensity to the oral production, yet, never totally completing the process.

Most importantly, because the storyteller belongs to the community, he becomes, in Hélias's text more specifically, the representative of the whole community and since he is never being described, he quickly grows to be a voice rather than an individual. The storyteller has no active role in the development of the plot. The reader never learns about his past or his characteristics, and he soon becomes a bodiless voice. It is a way of reinforcing the idea that he is essential to the text and to his community because he embodies a cultural ideal; he becomes the Breton Storyteller. $\mathrm{He}$ is portrayed as an outlet, a hole in the sense that he is only a source of knowledge, a mouth through which a cultural truth bursts. "His story- 
bag is bottomless" the narrator of Le Cheval d'orgueil explains. In Thomas's text, his interior voice is similarly described as a spring. As soon as he starts reciting, singing or telling his poem, his words become a river and forms an enormous swell that mesmerizes his audience ( $\mathrm{La}$ Chronique 21). ${ }^{20}$ For Danvez, his destiny and tasks are unambiguous: "the Creator gave me a genuine gift; that is my voice, he says" (37). Who he is does not really matter because it is more his role and his power that count.

In Hélias's other text, La Nuit singulière, the storyteller is the most dominant since it mainly portrays a collage of stories and of storytellers. It presents, indeed, seven individuals whose purpose is to gather during the night of the solstice and to share their traditional tales and past treasures. The text is mainly a continuous delivery of tales in which each character participates at some time. The narrator explains: "the orator was asked to let his word carry himself letting everything come out of his mouth without trying to organize or control it." Inspired from Marguerite de Navarre's Heptaméron and Dante's Décameron, La Nuit singulière portrays seven characters gathered around the dinner table. They share nothing but their love of peculiar stories that only the provided setting and time allow to narrate. ${ }^{21}$ As each storyteller is the natural source from which the knowledge flows, he therefore does not need to add transitions or connections to his narrations. Only a frail introduction such as "The story I am about to tell you" or "Now, let me tell you a story" or "let me start" is sometimes offered to the reader. They do not need to be introduced because they are self-sufficient. As for Grall, storytellers and bards are the Kings of Brittany. They are the essence of their civilization. According to the author, their leader is Glenmor, Glen meaning the earth and Mor meaning the ocean. He represents strength, unity and harmony. In $L a$ Nuit singulière, when their task is completed, each storyteller then falls silent and gives his place to the next participant. Sometimes, one story then ties to the next. Elsewhere, one story contains another one in a mise en abime. Some characters are then described as being storytellers as well: "The two men would recount extraordinary stories taking sincere pleasure in using their imagination, away from daily topics" (199). ${ }^{22}$ Educating, transmitting the language, reuniting the community and entertaining them, the storyteller becomes over time the guardian of the Breton imaginary. world and by the end he leads to the continuity of the legend.

What might be the most intriguing detail about the storyteller is the fact that he never appears by coincidence. I mentioned in the first part 
that orality is a concept often ostracized. I would like to show now that this prevailing trend overlooks the fact that folktales belong quite to the contrary, to a very sacred and ritualised act or art. They appear indeed in very orchestrated contexts as they are collective and cultural phenomena. In L'histoire des contes, Catherine Velay-Vallautin explains that an oral literature is undeniably anchored in a specific context and can only exist when surrounded by a complex system such as a social gathering. It therefore needs a specific space and time to blossom..$^{23}$ In early $1930 \mathrm{~s}$, Giono describes in Manosque des plateaux the importance of the storyteller and the influence the night has on him. He states that in each village an average man becomes a storyteller at night time, infused by the night (26). ${ }^{24}$

In the works of Hélias, Grall and Thomas, if storytellers are vital to the text, they also need to create for themselves a very unique space and moment to complete their tasks. Within Brittany where they wander, from village to village, the storytellers establish a very specific environment for their art, but most importantly, they elect night time as their moment of predilection. In addition to being the masters of the oral world, they become, above all, the stage managers of the night. Hélias, Grall and Thomas elect undeniably the night-time to anchor him as their symbolic character. In Le Cheval d'orgueil, the storyteller mainly appears during night-time gatherings as well. The narrator even describes the storyteller as a "night cat" (102). The fact that Hélias chooses La Nuit singulière (a peculiar night) for title is no mere coincidence. Nor it is a coincidence if Grall names his book, Fête de nuit, a night celebration. In the first one, the characters, as previously mentioned, gather only during the solstice. ${ }^{25}$ In the second one, they meet only at night time in dark and crowded bars. There, they find the power and courage to express the possibility of a rebellion against a centralized Nation and against Paris. Ultimately, that confined space allows them to dream of a better future for the Brittany they love and remember. Thomas also presents her characters as night owls. In La Chronique des choses, mornings are dramatic for Danvez, the poet, as they evoke dark thoughts (48). The narrator describes how "nighttime is when inspiration and debauchery reach their height. ... His nightly excess is in stark contrast with his peaceful manners during day time" (134). Thanks to the storytellers, their night assemblies become "exhibitions and real ceremonies." 26

Night has been a specific emblem for years. In various cultures, the night facilitates communion, cultural and social exchanges. It is also the time when ancestors come back to connect with the living ones. In $L a$ 
Traversée de la Mangrove, Condé gives details about that specific instant: "During the windiest nights, I call to my rescue all those who loved me but who are today gone... . They come and sit at my bedside and comfort me, telling me the tales of my childhood" (104). There again, the storyteller and night time are closely connected. In her study Écrire la parole de nuit, Bertène Juminer explains that during the colonizing era, slaves could only gather at night-time to celebrate their roots, their cultural customs and speak their own language freely. ${ }^{27}$ According to her, the storyteller took possession of this moment as a way to exalt his culture against the other culture of the colonizing domination.

Here, I would like to suggest that the darkness of the setting in which the authors anchor their characters is the key to their success and to their impact on the audience. It also leads to various consequences. First, it allows more secrecy to the storyteller. In a dark place, he can't be seen as well by his audience. He is therefore protected from the outside world and he can proudly disclose his native identity. The night is, then, the time when the Breton population can finally escape the control and constraints of state laws. Brittany, like most of the provinces françaises, has been since 1789 - date of the French Revolution - under the strict surveillance of a centralized France, centred in Paris. As Bretons had to assimilate into French society, they were denied the right to keep their own customs and had to adopt the dominant French language. In Le Cheval d'orgueil, Hélias often recalls the taboo that surrounds the Breton language. He describes how children were forbidden to speak Breton during the day, while studying at school. School time was designed to teach one unified and unifying language, the French one. As a consequence, I suggest that daytime pertains to "Frenchness," to cultural and social domination and restrictions, while night-time pertains to leisure, sensual pleasure, cultural and social exchange and freedom. Night therefore becomes not only a playful moment but also the time of collective and cultural intimacy, a time when people re-connect with each other, where the focus is back on the private life, the private sphere opposed to the public sphere. Secondly, the night allows the storyteller to protect the Breton cultural prophecy from the outside space. He can therefore keep the intimate heritage secret. He can decide to whom he will pass on his cultural treasures. From the moment the storyteller appears, he gives a new opacity to his culture, protecting it from the outside, keeping cultural secrecy hidden.

In the texts of Hélias, Grall and Thomas, the night becomes the permissive space of the disowned word. Because of his special link with 
the society and his own storytelling gift, the storyteller becomes the only master of both orality and the night. Like Robin Hood, he is a nomadic character; he gives back to his community what is taken away from them during the daytime. The three authors allow the storyteller to revive a tradition and to regain total power in a contemporary world. They portray him as the symbol of cultural reunification.

Here, I'd like to borrow Patrick Chamoiseau's idea according to which, as the sole legatee of orality, the storyteller is the "only man standing in darkness," alone facing the rest of his community, against the Other. Trapped on his pedestal, he becomes victim of his status to a certain degree. First, within the circle of life, of knowledge, of exchange, he gives wonders, oblivion, distraction, laughter, hope and the key to resistance. Yet at the end, he stands by himself. $\mathrm{He}$ is the one at the center of the circle educating and entertaining alone his society. Secondly, as a storyteller and a poet, he sometimes find himself, alone once more, lost in the dark, in the unknown world, helpless in his quest for a better Brittany. At the end of Fête de nuit, Grall's other novel, the main character, Arzel, embarks alone in his last journey. Hopelessly witnessing the destruction of his motherland, he decides to commit suicide after having killed the regional representative. Finally, alone again, the storyteller learns to voice a strong personal engagement. As Juminer explains in regards to the Caribbean literature, even remembering, delivering their stories and recreating a past world for a minute is an act of cultural safeguarding, but most importantly an act of rebellion and resistance. Telling a story is in this sense a protest and an anti-establishment act. The storyteller transgresses the forbidden that the Centre imposes on the peripheral areas. His mobility enables him to further escape the forbidden and to set himself free from the norm. So even though the storyteller might seem doomed because he remains a marginal character, he becomes a cultural and social icon and the redeemer of a whole population longing for memories and stories. Storyteller and folk tales become the essential emblems of the Breton text as they exemplify a literary creation. Through them, authors reflect the cry of a whole population dominated and somewhat colonized by Paris, what Régine Robin calls the "Franco-French genocide."

However, one could argue that today's social and cultural contexts are different. The world values fast, wide, and practical information. Efficiency seems to be everyone's first priority. One could then agree with Benjamin, who once said that at a time where the gift for listening is lost, "experience has fallen in value and the community of listeners 
disappears" ("The Storyteller" 83). One could state that the storyteller is indeed disappearing and that "the art of storytelling is reaching its end because the epic side of truth, wisdom, is dying out," as Benjamin once described it. One could further add that "the storyteller in his living immediacy is by no means a presence force, [as] he has already become something remote from us and something that is getting even more distant" (83). One could claim that the living speech as a narrative form is no longer possible due to "concomitant symptoms of the secular productive forces of history" (87). It is a fact indeed that the storyteller is no longer a dominant figure in most modern societies. Storytelling is not what it used to be; it has lost its essence. The storyteller has been transformed into a novel writer and the listener into a reader. Yet, folktales are still very much a part of most people's education and growing experiences. As much as men think of themselves as products of technology, they are still influenced by traditional values. In that sense, Hélias, Grall and Thomas would claim that the storyteller and his art prevail.

In the eyes of the three authors gathered in this study, indeed, creation involves a communication of experiences along with a reactivation and renewal of past treasures. Unlike other novelists, they refuse to isolate themselves in order to be productive. On the contrary, they greatly benefit from the interaction with the Other. Grall, Hélias and Thomas have successfully created a storyteller as a real imaginative response to what may have been an oppressing situation and environment. As they emphasize on the importance of the storyteller and of his gift, they insist on the fact tradition and modernity can rally and co-produce a meaningful literature, not only to Brittany but the whole metropolitan France and Francophone world. They insist that the "A nous deux maintenant!" shouted by Rastignac challenging Paris, in Balzac's Le Père Goriot, is no longer unavoidable nowadays. ${ }^{28}$ While marking the time for a return to their cultural roots, they declare that a whole intellectual world exists beyond Paris. These authors have successfully transmitted Breton characteristics even while using the dominant French language. They have created a literary space where the oral storyteller encounters the written tradition, each strengthening the other. Standing alone at a crossroad, at an 'in-between,' amid modernity and traditional values, between Brittany and Paris, Hélias, Grall and Thomas bridge the gap between orality and scripturality and bring them to a prolific interdependence. As they choose the night as their specific space and time, and this controversial orality as their resource, they transcend the 
misconception of the storyteller and turn his words into a powerful night lyric and a source of cultural liberation and exaltation. With their storyteller, "the unbound word dashes free endlessly until the end of the night." ${ }^{29}$ After all, maybe Yeats was right when he called the Breton "the people of twilight"?

\section{Duke University}

\section{Notes}

1. "Le Festival du conte et des arts de la parole," April 13th-19th.

2. "On croyait les conteurs disparus, engloutis dans les fracas des médias. ... Les voilà qui reviennent, parce que les gens ont besoin des légendes, des mythes et des histoires pour vivre." < www.Conteur.com $>$

3. Les deux frères, an Egyptian tale, is dated from thirteenth-century B.C. Les Contes de ma mère l'Oye written by Charles Perrault form the seventeenth-century, Les Contes de l'Alhambra written by Washington Irving in the eighteen-nineteenth-centuries, or the stories of H.C. Andersen in the nineteenth-century could be quoted here as exemplary as well. In twentieth-century France, the Ecole Rustique produced also folktales such as Le Trésor des contes written by Henri Pourrat. In the field of Francophone literature, we could refer to Le Pagne noir of Bernard Dadié, Les Nouveaux contes d'Amadou Koumba of Birago Diop, or Les Contes du pays incertain of the Quebecois Jacques Ferron.

4. Jean Giono, Manosque des plateaux (Paris: Gallimard, 1986) 27: "Il se sont assis à côté de moi. Quand je m'arrêtais, ils demandaient: Et après ?...Et alors?..."

5. Hélias, Lettres de Bretagne 34: "le jaillissement de l'inspiration."

6. Jean-Jacques Rousseau, Fragment sur la prononciation 1249: "les langues sont faites pour être parlées, l'écriture ne sert que de supplément de la parole...." Quoted in Jean-Louis Boissier.

7. Mona Thomas, La Chronique des choses 26: "Inconséquent. Jeune. Présomptueux. D'où tiens-tu cette folie! Imprimer!"

8. Benjamin, "The Storyteller," Illuminations 178: "Son talent naturel est de pouvoir narrer sa vie; sa dignité est de la pouvoir conter toute entière."

9. Hélias, Le Quêteur de mémoire 204-05.

10. Gramophone, Film, Typewriter.

11. Hélias, Le Cheval d'orgueil.

12. "Il va tenir boutiques de contes." 
13. "Quand le soir tombe, grand-père commence à conter pour deux ou trois galopins qui sont bientôt six ou sept autour de lui avec leurs paniers. [Les parents] ne voyant pas revenir les garçons et les filles ... retournent au champ. Les enfants sont agglutinés contre un talus, au milieu le sabotier qui raconte "comment un Breton devint roi d'Angleterre." Les parents n'osant pas interrompre le conteur, s'assoient un moment pour l'écouter. Après quoi ils ne songent plus à se lever."

14. "Mon grand-père m'apprend ces jours de la semaine qui commencent tous par 'di,' c'est drôle. 'Dilun, dimeurz, dimerher, diriaou, digwener, disadorn, disul. . . ." Je m'étonne que sa tête avec tout ce savoir n'éclate pas en morceaux."

15. Hélias, La Nuit singulière 16: the Rougeaud, both character and storyteller, concludes his presentation explaining that: "Il avait eu raison, après une lutte à mort, du plus grand loup qui ait jamais fait son apparition dans le pays."

16. Thomas, La Chronique des choses 7: "D'où qu'ils viennent, quoi qu'ils disent, [ses] mots sont une musique en lui, le texte n'est nulle part écrit."

17. "Danvez raconte les histoires dans mille variantes connues et d'autres de son crû. . . . C'est vrai, c'est conforme, les choses se sont déroulées ainsi. Or, pour Danvez, la vérité est diverse."

18. "Le Chanteur arrive! ... Il se fraye un passage dans la foule des bestiaux et des cordes. . . . On va l'écouter, on réclame les paroles. Il a mémoire prodigieuse."

19. "Son nom est répété, on prononce son éloge, qui ne désire l'écouter!"

20. "Danvez écoute sa voix intérieur. . . Il chante, un déferlement résonne."

21. This is mainly the reason why we chose the Peculiar Night as the translation of La Nuit singulière.

22. "Les deux hommes s'engageaient dans des récits extraordinaires pour le seul plaisir d'exercer leur imagination hors de tous les sujets courants."

23. Velay-Vallautin, L'histoire des contes.

24. "Des villages qui ont leur conteur comme on a son garde champêtre et son facteur. C'est dans le jour parfois un simple savetier, parfois un charron, parfois un simple qui bavote doucement, à l'ombre, à longueur de sieste. Mais le soir. ... Il est tout imbibé de nuit."

25. Grall, Fête de nuit.

26. Hélias, Les Autres et les miens 109. 
27. Juminer, Ecrire la parole de nuit.

28. Balzac, Le Père Goriot 276.

29. < <ww. Conteur.com> : "La parole filera à jamais en toute liberté jusqu'au bout de la nuit.

\section{Works Cited}

Balzac, Honoré de. Le Père Goriot. Paris: Garnier Flammarion, 1996. Benjamin, Walter. "The Storyteller - Reflections on the Works of Nikolai Leskov" Illuminations. New York: Hartcourt, 1969. 83-109

Boissier, Jean-Louis. Moments de Jean-Jacques Rousseau, confessions et rêveries. Paris: Gallimard, 2000.

Condé, Maryse. La Traversée de la Mangrove. Paris: Gallimard, 1992.

Eiland, Howard \& Michael W. Jennings. Eds. Walter Benjamin: Selected

Writings Vol. 3 [1935-1938]. Boston: Harvard UP, 2002

Gandillac, Marucie. Trans. Rastelli raconte... et autres récits. By Walter Benjamin. Paris: Denoël, 1971.

Grall, Xavier. Fête de nuit. Saint-Brieuc: Kelenn, 1971. Reed 1972.

—. Le Cheval couché. [Hachette, 1976] Reissued. Quimper: Calligrammes, 1998.

Hélias, Pierre-Jakez. Ar Men, La Pierre noire. Brest: Emgleo Breiz, 1964. -. Le Cheval d'orgueil. Paris: Plon, 1975.

- Les Autres et les miens. Paris: Plon, 1977.

—. Lettres de Bretagne. Paris: Galillée, 1978.

-. Vent de soleil. Paris: Ed. de Fallois, 1988.

—. La Nuit singulière. Paris: Ed. de Fallois, 1990.

—. Le Quêteur de mémoire. Paris: Plon, 1990.

Juminer, Bertène. La Parole de nuit. Paris: Gallimard, 1994.

Kittler, Friedrich. Gramophone, Film, Typewriter. Trans. A. Geoffrey Winthrop-Ound and Michael Wutz. Stanford: Stanford UP, 1999.

Thomas, Mona. La Chronique des choses. Seyssel: Champ Vallon, 2002. Velay-Vallautin, Catherine. L'histoire des contes. Paris: Fayard, 1992. 